\title{
Pharmaciana
}

Vol.7, No.1, Mei 2017, Hal. 105-112

ISSN: 2088 4559; e-ISSN: 24770256

\section{Aktivitas imunostimulan ekstrak bawang putih tunggal pada mencit yang diinduksi Escherichia coli}

\author{
Oki Sandra Agnesa ${ }^{1}$, Herawati Susilo ${ }^{2}$, Sri Rahayu Lestari ${ }^{2}$ \\ ${ }^{1}$ Program Magister Pendidikan Biologi Universitas Negeri Malang \\ Jl. Semarang No.5 Malang 65145 \\ ${ }^{2}$ Jurusan Biologi FMIPA Universitas Negeri Malang \\ Jl. Semarang No.5 Malang 651145
}

Submitted: 12-03-2017

Reviewed: $20-03-2017$

Accepted: 06-05-2017

\begin{abstract}
ABSTRAK
Bawang putih tunggal telah banyak digunakan masyarakat sebagai obat tradisional salah satunya untuk meningkatkan stamina. Penelitian ini bertujuan untuk mengetahui pengaruh pemberian ekstrak bawang putih tunggal sebagai imunostimulan melalui pengujian aktivitas dan kapasitas fagositosis makrofag serta berat limpa mencit (Mus musculus) yang diinduksi dengan bakteri Escherichia coli. Mencit jantan (Balb-C, umur 12 minggu, BB $20 \pm 5$ g) diberi ekstrak bawang putih tunggal selama 28 hari berturut-turut dengan dosis ekstrak bawang putih tunggal $\mathrm{N} 0 \%, \mathrm{P} 10,25 \%, \mathrm{P} 2$ 0,5\%, P3 1\%, dan P4 2\% yang diberikan sekali sehari. Pada hari ke 29, mencit diinduksi dengan bakteri E.coli yang diberikan secara intraperitoneal $\left(1 \mathrm{~mL}, 1,5 \times 10^{5} \mathrm{cfu} / \mathrm{mL}\right)$. Aktivitas fagositosis makrofag dihitung dari sediaan apusan cairan peritoneum. Ekstrak bawang putih tunggal meningkatkan jumlah dan kapasitas makrofag aktif secara nyata pada perlakuan $\mathrm{P} 2, \mathrm{P} 3$, dan $\mathrm{P} 4(p=0,000 ; \alpha=0,05)$ dengan berat limpa yang berbeda secara signifikan $(p=0,000 ; \alpha=0,05)$. Hasil penelitian menunjukkan semakin tinggi ekstrak bawang putih tunggal yang diberikan maka semakin tinggi pula aktivitas dan kapasitas fagositosis makrofagnya dengan berat limpa yang semakin kecil.
\end{abstract}

Kata kunci: bawang putih tunggal, fagositosis makrofag, imunostimulan.

\begin{abstract}
Single garlic has been used as traditional medicine for increasing stamina. This research aim was to know the effect of single garlic as immunostimulant through activity and phagosytosis capacity of macrophage and weight of mice spleen that induced by E.coli. Male mice (Balb-C, 12 weeks old, weight $20 \pm 5 \mathrm{~g}$ ) was treated by single garlic extract for $28^{\text {th }}$ days (once per days) with various dosage (N 0\%, P1 0.25\%, P2 0.5\%, P3 1\%, and P4 2\%). On day 29, mice were induced by E.coli through intraperitoneal injection $\left(1 \mathrm{~mL}, 1.5 \times 10^{5} \mathrm{cfu} / \mathrm{mL}\right)$. phagocytosis activity of macrophage was counted by peritoneum liquid smear. Single garlic extract increase amount and capacity of active macrophage in $\mathrm{P} 2, \mathrm{P} 3$, and $\mathrm{P} 4(p=0,000 ; \alpha=0.05)$ with significant various spleen weight $(p=0.000 ; \alpha=0.05)$. The result showed that the higher dose of single garlic extract can make higher activity and capacity of phagocytosis of macrophage and lower spleen weight.
\end{abstract}

Keywords: single garlic, macrophage, immunostimulant.

Penulis korespondesi:

Sri Rahayu Lestari

Jurusan Biologi FMIPA Universitas Negeri Malang

J1. Semarang No.5 Malang 651145

E-mail: srirahayulestari@um.ac.id 


\section{PENDAHULUAN}

Sistem kekebalan tubuh (imunitas) dapat didefinisikan sebagai kemampuan tubuh untuk mengidentifikasi dan menahan maupun menghilangkan sejumlah besar mikroorganisme menular dan berbahaya, memungkinkan tubuh untuk mencegah atau melawan penyakit dan menghambat kerusakan jaringan (Silverthorn, et al., 2010; Sethi dan Singh, 2015). Imunitas dibagi ke dalam dua bagian (imunitas bawaan dan adaptif) yang saling bekerja sama. Sistem kekebalan tubuh bawaan paling aktif di awal respon imun sedangkan kekebalan adaptif menjadi semakin dominan seiring berjalannya waktu (Guyton dan Hall, 2006; Silverthorn, et al., 2010; dan Sherwood, 2011). Efektor utama imunitas bawaan meliputi granulosit, monosit/makrofag, sel pembunuh alami, sel mast dan basofil. Efektor utama imunitas adaptif adalah sel limfosit B \& T. Sel-sel ini penting dalam respon kekebalan normal terhadap infeksi dan tumor, serta memediasi penolakan transplantasi dan autoimunitas (Krensky et al., 2011).

Respon imun dapat diperkuat dengan bantuan asupan senyawa kimia dari luar. Salah satunya adalah senyawa kimia yang berkemampuan sebagai imunomodulator. Imunomodulator adalah zat biologis atau sintetis yang dapat merangsang untuk menekan atau memodulasi setiap aspek dari sistem kekebalan tubuh (Lake et al., 2012). Imunomodulator klinis dapat diklasifikasikan ke dalam 3 kategori. Immunoadjuvants digunakan untuk meningkatkan efektivitas vaksin dan dapat dianggap stimulan imun spesifik. Imunosupresan adalah kelompok struktural dan fungsional heterogen dari obat yang umumnya diberikan dalam regimen kombinasi untuk mengobati berbagai penyakit autoimun dan mencegah penolakan transplantasi. Imunostimulan meningkatkan daya tahan tubuh terhadap infeksi yang pada dasarnya bekerja secara tidak spesifik (Lake et al., 2012; Sethi, dan Singh, 2015).

Obat tradisional dievaluasi melalui kegiatan penelitian yang luas untuk melihat efek terapi potensial yang dimilikinya (Sethi, dan Singh, 2015). Salah satu tanaman yang memiliki spesifikasi sebagai tanaman obat, telah diteliti dengan serius selama beberapa tahun, dan digunakan selama berabad-abad untuk memerangi penyakit adalah bawang putih (Gebreyohannes dan Gebreyohannes, 2013). Bawang putih (Allium sativum L) adalah anggota tanaman dari keluarga Liliaceae (IT IS Report, 2016), telah diakui secara luas sebagai tanaman rempah yang bernilai ekonomi tinggi dan obat untuk berbagai penyakit serta gangguan fisiologis (Papu et al., 2014). Bawang putih yang sekarang tumbuh di seluruh dunia diduga berasal dari Asia Tengah dan merupakan salah satu tanaman yang pertama kali dibudidayakan manusia (Kemper, 2000). Bawang putih mengandung zat farmakologis yang berguna meliputi 33 senyawa sulfur, beberapa enzim, 17 asam amino, dan mineral seperti selenium (Singh dan Singh, 2008).

Bawang putih memiliki banyak peran bagi kesehatan diantaranya dapat menghambat dan membunuh bakteri, jamur, menurunkan (tekanan darah, kolesterol darah, dan gula darah), mencegah penggumpalan darah, dan mengandung sifat anti-tumor (Gebreyohannes \& Gebreyohannes, 2013; Papu et al., 2014). Bawang putih juga dapat meningkatkan sistem kekebalan tubuh untuk melawan penyakit potensial dan menjaga kesehatan (Papu et al., 2014) melalui peningkatan monosit dan aktivitas fagositosis (Aly et al., 2008) dan meningkatkan level antibodi (Eid \& Iraqi, 2014). Bawang putih juga dianggap sebagai antioksidan yang efektif untuk melindungi sel terhadap kerusakan radikal bebas, serta dapat membantu mencegah beberapa jenis kanker, penyakit jantung, stroke dan infeksi virus (Gebreyohannes dan Gebreyohannes, 2013; Papu et al., 2014). Bawang putih sebagai antibakteri alami adalah salah satu imunostimulan alami yang efektif (Londhe et al., 2011), bekerja dengan cara memfasilitasi fungsi sel-sel fagositik dan meningkatkan kegiatan bakterisidanya (Erguig, et al., 2015). Sifat antibakteri dari bawang putih dapat dikaitkan dengan allicin yaitu komponen imunologi aktif bawang putih, telah ditemukan untuk mempengaruhi stres oksidatif dan respon imun dalam beberapa sistem eksperimental (Erguig et al., 2015).

Bawang putih memiliki beberapa varietas salah satunya adalah bawang putih tunggal (Neeraj et al., 2014). Di Indonesia terdapat varietas bawang putih tunggal yang dikenal dengan nama bawang lanang. Bawang lanang sebenarnya merupakan bawang putih yang hanya terdiri dari satu suing dikarenakan bawang ini tumbuh di lingkungan yang tidak sesuai (Untari, 2010). Bawang lanang termasuk jenis bawang khusus yang hanya ditemukan di daerah tertentu di Indonesia salah satunya 
pulau Jawa. Bawang lanang memiliki aroma yang lebih menyengat bila dibandingan dengan bawang yang lain, hal ini bisa menjadi salah satu indikator bahwa zat yang terkandung dalam bawang lanang jumlahnya lebih banyak dibandingkan jenis bawang lain (Utami dan Mardiana, 2013). Tujuan dari penelitian ini adalah untuk mengetahui aktivitas imunostimulan dari bawang putih tunggal dengan menggunakan hewan coba berupa mencit yang diinduksi dengan bakteri E.coli.

\section{METODE PENELITIAN}

Penelitian ini adalah penelitian eksperimental laboratorium dengan post test only control group design. Adapun metode penelitiannya sebagai berikut (No ethical clearance 1056/UN10.14/AK/2016).

\section{Alat dan Bahan}

Hewan coba menggunakan mencit jantan Galur Balb-C umur 12 minggu dan berat badan $20 \pm 5 \mathrm{~g}$ sebanyak 25 ekor yang diperoleh dari Malang Murine Farm, Singosari-Malang. Tumbuhan yang diuji adalah umbi bawang putih tunggal lokal Tengger diperoleh dari daerah Ngadas Poncokusumo yang diperjualbelikan di Pasar Tumpang-Malang dan diekstraksi di Balai Materia Medika, Batu-Malang. Bakteri uji yang digunakan adalah Escherichia coli $\left(1,5 \times 10^{5} \mathrm{cfu} / \mathrm{mL}\right)$ yang diperoleh dari Laboratorium Mikrobiologi, FMIPA Universitas Negeri Malang.

\section{Jalannya Penelitian}

Prosedur kerja pada penelitian eksperimen ini adalah sebagai berikut.

\section{Pembuatan ekstrak bawang putih tunggal}

Ekstrak bawang putih tunggal diperoleh dengan cara ekstraksi soxhlet dengan pelarut heksan. Satu kali running proses soxhletasi diperlukan sebanyak $200 \mathrm{~g}$ serbuk bawang putih tunggal dengan heksan sebanyak $2,4 \mathrm{~mL}$. Hasil ekstraksi diuapkan menggunakan rotary evaporator dan ekstrak yang diperoleh berbentuk cair ditempatkan dalam tabung.

\section{Perlakuan ekstrak bawang putih tunggal}

Mencit diaklimasi selama 7 hari diberi pakan berupa pellet Hi-Gro (10 gram/ekor) serta diberi minum secara ad libitum. Dua puluh lima hewan coba (mencit) dibagi dalam 5 kelompok, diberikan ekstrak bawang putih tunggal dengan konsentrasi N $(0 \%+$ Hi-Gro $) ; \mathrm{P} 1(0,25 \%+\mathrm{Hi}-\mathrm{Gro}) ; \mathrm{P} 2(0,5 \%+$ Hi-Gro); P3 (1\%+ Hi-Gro); P4 (2\%+ Hi-Gro). Ekstrak diberikan secara oral (gavage) sebanyak 0,3 $\mathrm{ml} /$ ekor/hari selama 28 hari. Ekstrak bawang putih tunggal diencerkan dengan menggunakan minyak jagung. Pada hari ke 29 setiap mencit diinfeksi dengan $1 \mathrm{~mL}$ suspense bakteri E.coli dan dibiarkan selama 3 hari. Mencit dieutanasi dan disuntikkan $5 \mathrm{~mL} \mathrm{NaCl} 0,9 \%$ pada bagian peritoniumnya, dibiarkan selama 20 menit. Cairan peritoneum diambil, dipulas pada gelas objek, difiksasi dengan methanol selama 3 menit, diwarnai dengan pewarna Giemsa, didiamkan 3 menit, dibilas dengan air mengalir. Setelah sediaan kering dihitung aktivitas dan kapasitas fagositosis makrofag dengan bantuan mikroskop. Aktivitas fagositosis makrofag ditetapkan berdasarkan jumlah sel fagosit yang aktif melakukan fagositosis dalam 100 sel fagosit, sedangkan kapasitas fagositosis makrofag ditetapkan berdasarkan jumlah bakteri E.coli yang difagositosis oleh 50 sel fagosit aktif. Berat limpa juga diamati dengan menimbang limpa mencit (berat limpa relatif $=($ berat limpa: berat badan $) \times 100 \%)$.

\section{Analisis Data}

Analisis data menggunakan software SPSS 17 untuk pengujian normalitas, homogenitas, dan analisis variansi satu arah (ANOVA). Analisis variansi digunakan untuk mengetahui pengaruh ekstrak bawang putih tunggal dengan berbagai serial konsentrasi dosis. Apabila nilai $\mathrm{F}_{\text {hitung }}$ lebih besar dari nilai $\mathrm{F}_{\text {tabel }}$ pada tingkat kepercayaan $95 \%$, maka akan dilanjutkan dengan uji Duncan's Multiple Range Test (DMRT) untuk membandingkan hasil dan melihat perbedaan pada tiap perlakuan (tingkat konsentrasi dosis). 


\title{
HASIL DAN PEMBAHASAN
}

Aktivitas imunostimulan ektrak bawang putih tunggal pada mencit jantan yang diinduksi dengan bakteri E.coli dilihat dari aktivitas dan kapasitas fagositosis makrofag serta berat limpa relatif. Pemberian ekstrak bawang putih tunggal menunjukkan pengaruh yang signifikan terhadap aktivitas fagositosis makrofag $(p=0,000 ; \alpha=0,05)$. Terjadi peningkatan aktivitas fagositosis makrofag dari kelompok yang tidak diberi ekstral bawang putih tunggal hingga kelompok yang diberi dosis tertinggi ekstrak bawang putih tunggal. Berturut-turut peningkatannya mulai dari $42 \pm 1 \%$ makrofag aktif $(\mathrm{N})$, $42,67 \pm 0,58 \%$ makrofag aktif (P1), $63 \pm 3 \%$ makrofag aktif (P2), $76 \pm 1 \%$ makrofag aktif (P3), dan 88 $\pm 1 \%$ makrofag aktif (P4) (Gambar 1). Pemberian dosis ekstrak bawang putih tunggal yang berbeda memberikan pengaruh yang berbeda pula pada aktivitas fagositosis makrofag, di mana semakin tinggi dosis yang diberikan maka semakin tinggi pula aktivitas fagosistosis makrofagnya.

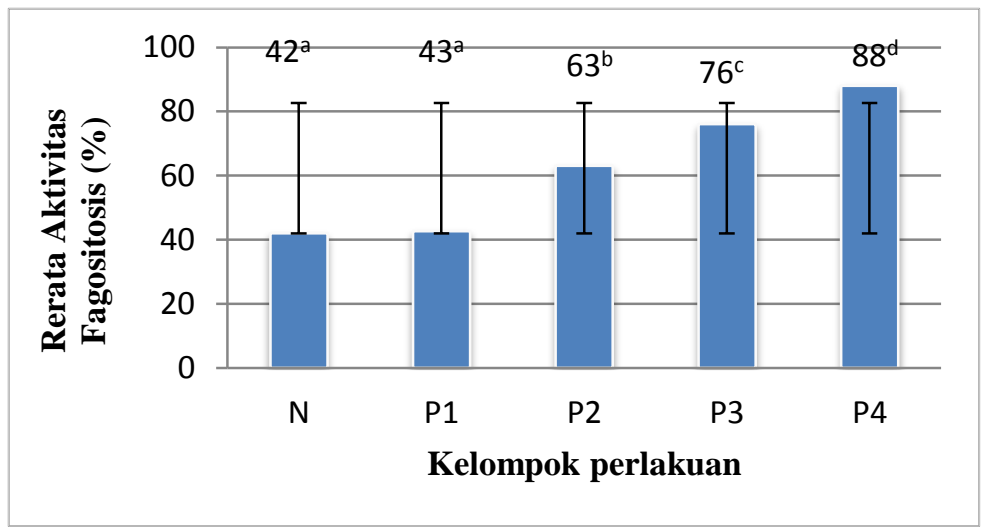

\section{Gambar 1. Rerata aktivitas fagositosis makrofag mencit yang diberi ekstrak bawang putih tunggal dan diinduksi E.coli}

\author{
Keterangan: \\ N : Kelompok yang hanya diinduksi dengan E.coli \\ P1 : Kelompok yang diberi ekstrak bawang putih tunggal konsentraso 0,25\% dan diinduksi E.coli \\ P2 : Kelompok yang diberi ekstrak bawang putih tunggal konsentraso 0,5\% dan diinduksi E.coli \\ P3 : Kelompok yang diberi ekstrak bawang putih tunggal konsentraso $1 \%$ dan diinduksi E.coli \\ P4 : Kelompok yang diberi ekstrak bawang putih tunggal konsentraso $2 \%$ dan diinduksi E.coli \\ Rerata yang dilambangkan dengan huruf yang sama menunjukkan tidak berbeda nyata pada uji Duncan's \\ Multiple Range Test
}

Jumlah sel bakteri yang difagosit makrofag dihitung sebagai kapasitas fagositosis makrofag. Pemberian ekstrak bawang putih tunggal menunjukkan pengaruh yang signifikan terhadap kapasitas fagositosis makrofag $(p=0,000 ; \alpha=0,05)$. Kapasitas fagositosis makrofag kelompok N memiliki ratarata $324,33 \pm 12,66$ bakteri/50 makrofag. Pemberian ekstrak bawang putih tunggal meningkatkan kapasitas fagositosis makrofag seiring dengan peningkatan dosis yang berikan mulai dari $335 \pm 17,35$ bakteri/50 makrofag (P1), $595 \pm$ 8,72 bakteri/50 makrofag (P2), 775,33 \pm 5,68 bakteri/50 makrofag (P3), dan $854 \pm 21,66$ bakteri/50 makrofag (P4) (Gambar 2). Pemberian dosis ekstrak bawang putih tunggal yang berbeda juga memberikan pengaruh yang berbeda pada kapasitas fagositosis makrofag, di mana semakin tinggi dosis yang diberikan maka semakin tinggi pula kapasitas fagosistosis makrofagnya.

Aktivitas dan kapasitas fagositosis makrofag yang semakin meningkat pada kelompok perlakuan (diberi ekstrak bawang putih tunggal) dibandingkan kelompok normal (tidak diberi ekstrak bawang putih tunggal) menunjukkan bahwa bawang putih tunggal terbukti memiliki aktivitas imunostimulan. Hal ini sejalan dengan beberapa hasil penelitian. Ekstrak bawang putih dapat meningkatkan proliferasi sel lien, sekresi IL-12, TNF- $\alpha$ dan IFN- $\gamma$, memperkuat aktivitas sel NK, dan menginduksi aktivitas fagositosis makrofag peritoneal (Kyo et al., 2001). Ekstrak bawang putih juga 
dapat meningkatkan daya tahan mencit Balb/C yang diinfeksi Listeria monocytogenes dinilai dari indeks fagositik makrofag, hitung kuman kultur organ hepar dan survivalnya (Sawitri E, 2003). Bawang putih juga meningkatkan respon imun bawaan meliputi jumlah total leukosit, respiratory brust (penggunaan oksigen pada proses fagositosis oleh sel fagositik),aktivitas fagositosis, indeks fagositosis, dan aktivitas lisozim (Ndong dan Fall, 2011).

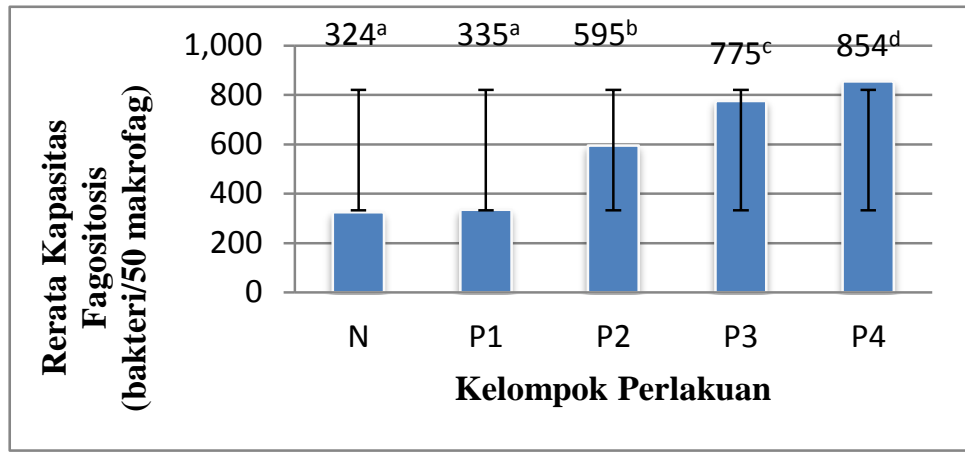

\title{
Gambar 2. Rerata kapasitas fagositosis makrofag mencit yang diberi ekstrak bawang putih tunggal dan diinduksi E.coli
}

Berat limpa juga dihitung untuk melihat aktivitas imunostimulan ekstrak bawang putih tunggal. Berat limpa yang dihitung adalah berat limpa relatif. Pemberian ekstrak bawang putih tunggal menunjukkan pengaruh yang signifikan terhadap berat limpa $(p=0,000 ; \alpha=0,05)$. Rata-rata berat limpa relatif mencit yang diinfeksi bakteri E.coli bertutut-turut $0,072 \pm 0,002 \%(\mathrm{~N}), 0,049 \pm 0,002 \%(\mathrm{P} 1)$, $0,066 \pm 0,003 \%$ (P2), 0,071 $\pm 0,002 \%$ (P3), dan 0,044 $\pm 0,003 \%$ (P4) (Gambar 3). Pemberian dosis ekstrak bawang putih tunggal yang berbeda juga memberikan pengaruh berbeda pada berat limpa, di mana berat limpa relatif $\mathrm{P} 4 \leq \mathrm{P} 1<\mathrm{P} 2<\mathrm{P} 3 \leq$ Kelompok $\mathrm{N}$.

Limpa merupakan organ limfatik terbesar dalam tubuh yang terdiri dari dua kompartemen besar yaitu white pulp dan red pulp. White pulp adalah jaringan limfatik yang mengandung limfosit dan makrofag (Tortora dan Derickson, 2009). Jika terjadi invasi oleh bakteri di dalam tubuh, respon imun bawaan (non-spesifik) akan melakukan respon primer dengan memperbanyak jumlah efektornya seperti makrofag, dan jika invasi terus berlanjut tubuh akan melakukan respon imun sekunder dengan mengaktifkan respon imun adaptif (spesifik) dengan memperbanyak jumlah efektornya seperti limfosit B dan limfosit T (Guyton dan Hall, 2006; Silverthorn, et al., 2010; dan Sherwood, 2011). Pengaktifan respon imun bawaan dan adaptif akan mempengaruhi jumlah efektor respon imun tersebut yang pada akhirnya mempengaruhi berat limpa. Hal ini dapat terjadi karena pada daerah white pulp mengandung lebih banyak sel limfosit dan makrofag dibandingkan pada keadaan respon imun inaktif. Pemberian ekstrak bawang putih tunggal pada mencit yang diinduksi dengan E.coli meningkatkan kemampuan fagositosis makrofag (dilihat dari aktivitas dan kapasitas fagositosisnya) dengan peningkatan tertinggi pada perlakuan P4. Diasumsikan bila kemampuan fagositosis makrofag meningkat, respon imun bawaan dapat menanggulangi invasi bakteri dan tubuh tidak melakukan respon sekunder (respon imun adaptif tidak diaktifkan) sehingga berat limpa tidak banyak berubah dari keadaan kedua respon imun inaktif, karenanya berat limpa pada P4 menunjukkan berat limpa terkecil.Sebaliknya pada perlakuan Kelompok N (tidak diberi ekstrak bawang putih tunggal) diasumsikan terjadi aktivasi pada kedua 
respon imun (bawaan dan adaptif) karena tidak ada penambahan imunostimulan dari luar tubuh, maka respon bawaan tidak cukup untuk menanggulangi invasi bakteri sehingga tubuh mengaktifkan respon adaptif untuk membantu menanggulanggi invasi, ditandai dengan berat limpa Kelompok $\mathrm{N}$ terbesar dari kelima perlakuan.
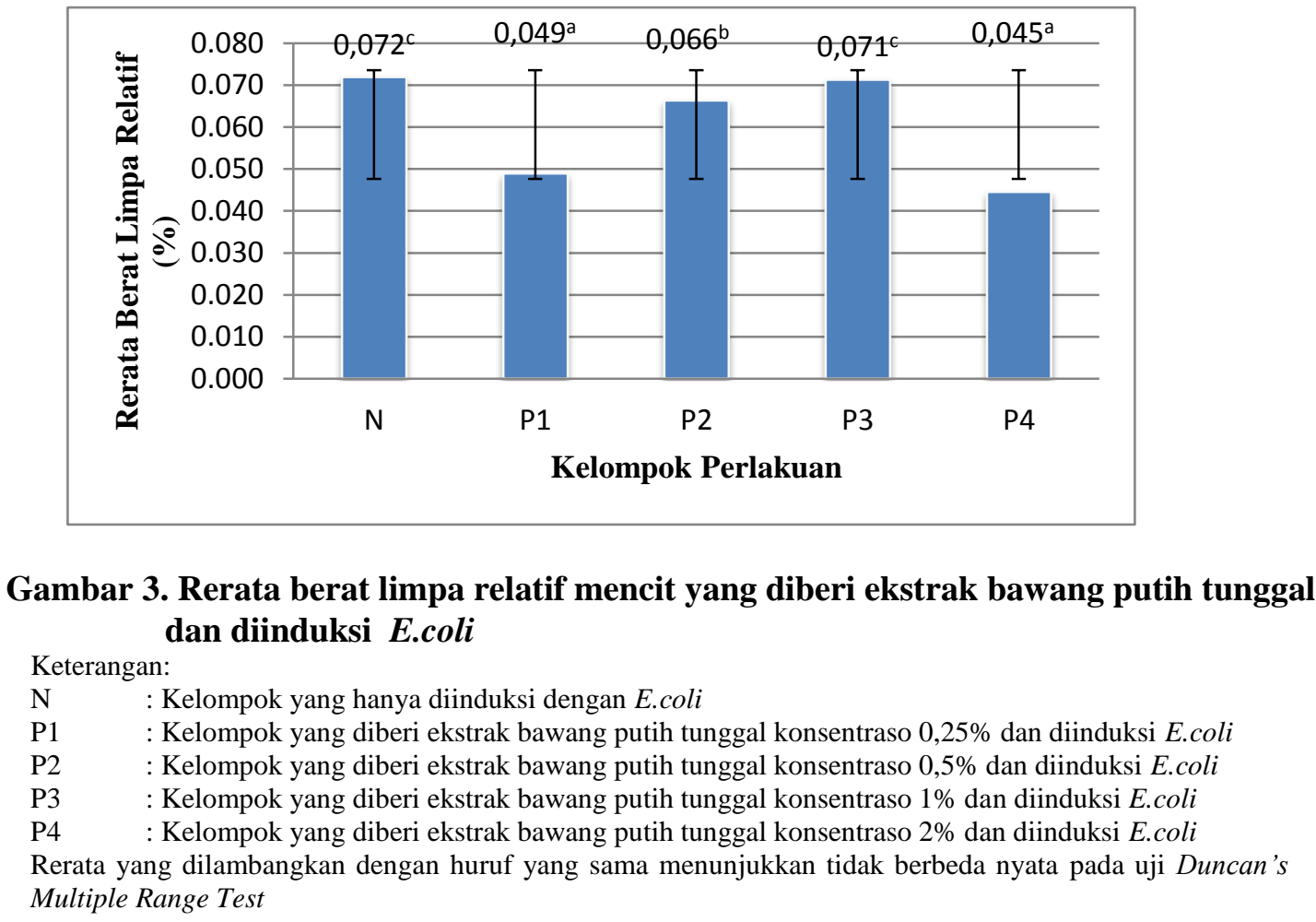

Aktivitas dan kapasitas fagositosis makrofag paling rendah dijumpai pada kelompok yang diberi dosis $0 \%$ kemudian meningkat seiring dengan peningkatan dosis ekstrak bawang putih tunggal yang diberikan. Aktivitas dan kapasitas fagositosis tertinggi dicapai oleh kelompok dosis tertinggi P4 dengan 2\% ekstrak bawang putih tunggal. Peningkatan aktivitas dan kapasitas fagositosis makrofag seiring dengan tingginya dosis menunjukkan bahwa terdapat bahan aktif yang terkandung dalam ekstrak bawang putih tunggal yang berpotensi untuk meningkatkan aktivitas dan kapasitas makrofag. Hal ini didukung dengan data berat limpa relatif, di mana pemberian ekstrak bawang putih tunggal mengaktifkan respon imun bawaan (non-spesifik) ditandai dengan berat limpa kelompok yang diberi ekstrak bawang putih tunggal lebih ringan dibandingkan dengan kelompok yang tidak diberi ekstrak bawang putih tunggal.

Bawang putih adalah tanaman obat yang memiliki peranan luas, salah satunya sebagai antibakteri (Erguig et al., 2015). Bawang putih sebagai antibakteri alami adalah salah satu imunostimulan alami yang efektif. Imunostimulan dapat meningkatkan kekebalan bawaan (nonspesifik) dengan meningkatkan jumlah fagosit atau mengaktifkan fagositosis (Shoemaker et al., 1997). Kandungan sulfur, asam amino, dan beberapa senyawa lainnya dari bawang putih diindikasikan sebagai salah satu konduktor yang merangsang fungsi kekebalan tubuh dengan membuat makrofag (Singh dan Singh, 2008; Gebreyohannes dan Gebreyohannes, 2013; Papu et al., 2014). Komponen bahan aktif bawang putih (misalnya allicin) meningkatkan stimulasi kekebalan tubuh dengan aktivasi mitogenik (Dorhoi et al., 2006). Efek imunostimulan allicin dalam bawang putih telah dilaporkan dalam banyak studi. Percobaan pada manusia dan tikus mengungkapkan bahwa penambahan ekstrak bawang putih meningkatkan fagositosis sel peritoneal dan meningkatkan produksi interleukin-2 (IL-2), IL-12, interferon dan tumor necrosis factor-alpha dari splenosit (Kyo et al., 2001; Lamm dan Riggs, 
2001;Chandrashekar et al., 2009; Osman et al., 2012), serta metabolisme yang keluar dari makrofag (Rehman dan Munir, 2015).

Berdasarkan uji stastistik dari masing-masing perlakuan memperlihatkan adanya perbedaan yang signifikan baik aktivitas dan kapasitas fagositosis makrofag maupun berat limpa relatif dari variasi dosis yang diberikan, dengan kata lain terdapat perbedaan yang bermakna dari aktivitas dan kapasitas fagositosis makrofag maupun berat limpa relatif dari variasi dosis yang diberikan. Aktivitas dan kapasitas fagositosis makrofag akan meningkat seiring dengan peningkatan dosis ekstrak yang diberikan (berbanding lurus) artinya semakin besar dosis ekstrak yang diberikan semakin besar aktivitas dan kapasitas fagositosisnya.

\section{KESIMPULAN}

Ada pengaruh pemberian ekstrak bawang putih tunggal sebagai imunostimulan melalui pengujian aktivitas dan kapasitas fagositosis makrofag serta berat limpa mencit (Mus musculus) yang diinduksi dengan bakteri Escherichia coli. Terjadi peningkatan aktivitas dan kapasitas makrofag didukung berat limpa seiring peningkatan dosis ekstrak yang diberikan dengan pengaruh terbesar ditunjukkan oleh dosis tertinggi (P4 2\% ekstrak bawang putih tunggal).

\section{UCAPAN TERIMAKASIH}

Penulis mengucapkan terimakasih kepada Ibu Dr. Sri Rahayu Lestari sebagai penyumbang dana untuk penelitian, teknisi di Balai Materia Medika, laboran di Lab.Mikrobiologi FMIPA Universitas Negeri Malang, dan rekan-rekan proyek penelitian yang telah membantu hingga terselesaikannya penelitian ini.

\section{DAFTAR PUSTAKA}

Aly, S. H., Atti, N. M. A., dan Mohamed, M. F, 2008, Effect Of Garlic On The Survival, Growth, Resistance And Quality Of Oreochromis Niloticus, $8^{\text {th }}$ International Symposium on Tilapia in Aquaculture 2008.

Chandrashekar PM, Venkatesh YP, 2009, Identification of the protein components displaying immunomodulatory activity in aged garlic extract, J Ethnopharmacol, 124(3):384-390.

Dorhoi A, Dobrean V, Zahan M, Virag P, 2006, Modulatory effects of several herbal extracts on avian peripheral blood cell immune responses. Phytotherapy Research, 20(5): 352-358.

Eid, K. M., \& Iraqi, M. M., 2014, Effect of garlic powder on growth performance and immune response for newcastle and avian influenza virus diseases in broiler of chickens. 2nd International Conference On Biotechnology Applications In Agriculture (ICBAA), Benha University, Moshtohor and Hurghada, 8-12, April 2014, Egypt.

Erguig, M., Yahyaoui, A., Fekhaoui, M., \& Dakki, M, 2015, The Use of Garlic in Aquaculture. European Journal of Biotechnology and Bioscience, 3(8): 28-33.

Gebreyohannes, G. \& Gebreyohannes, M, 2013, Medicinal values of garlic: A review. International Journal of Medicine and Medical Sciences, 5(9): 401-408.

Guyton, A. C. \& Hall, J. E, 2006, Textbook of Medical Physiology. Elevent Edition. Pennsylvania: Elsevier Inc.

IT IS Report. 2016, Allium sativum L, (Online), (http://www.itis.gov/ servlet/SingleRpt/SingleRpt? search_topic $=$ TSN\&search_value $=42652$ )

Kemper, K.J. 2000, Garlic, Makalah disajikan pada Longwood Herbal Task Force, (Online), (http://www.mcp.edu/herbal/default.htm)

Krensky AM, Bennett WM, Vincenti F, 2011, Immunosuppressants, Tolerogens and Immunostimulants. In "Goodman \& Gilman's The Pharmacological basis of therapeutics", 12th edition. New York: McGraw Hill Companies, Inc. Dari AccessMedicine, (Online), (http://accessmedicine.mhmedical.com/content.aspx? bookid=374\&sectionid=41266243)

Kyo E, Uda N, Kasuga S, Itakura Y, 2001, Immunomodulatory effects of aged garlic extract. J Nutr, 131(3): 1075-1079 
Lake DF, Briggs AD, Akporiaye ET, 2012, Immunopharmacology. In "Basic and Clinical Pharmacology" 12th edition. New York: Tata McGraw Hill New Delhi. Dari Access Medicine, (Online),(http://accessmedicine. $\mathrm{mhmedical} . \mathrm{com} /$ content .aspx ?bookid=388\&sectionid=4576428 1)

Lamm DL, Riggs DR. 2001, Enhanced immunocompetence by garlic: role in bladder cancer and other malignancies. J Nutr,131:1067-70.

Londhe V.P., Gavasane A.T., Nipate S.S., Bandawane D.D., \& Chaudhari P.D. 2011, Role Of Garlic (Allium Sativum) In Various Diseases: An Overview. Journal Of Pharmaceutical Research And Opinion, 1(4):129-134

Ndong, D. \& Fall, J, 2011, The Effect ff Garlic (Allium sativum) on Growth and Immune Responses of Hybrid Tilapia (Oreochromis niloticus X Oreochromis aureus). Journal of Clinical Immnunology and Immunopathology Research, 3(1):1-9.

Neeraj, S., Sushila, K., Neeraj, D., Milind, P., \& Minakshi, P, 2014, Garlic: A Pungent Wonder From Nature. International Research Journal of Pharmacy, 5(7): 523- 529.

Osman, M.T., Adnan, A., Bakar, N. S., \& Alashkham, F, 2012, The Potential Immunomodulatory Effect Of Allicin Administration In Autommune Disease Process Of Type 1 Diabetes Mellitus. International Journal of Pharmacy and Pharmaceutical Sciences, 4(5): 440-444.

Papu, S., Jalvlr, S., Sweta, S., dan Singh, B.R. 2014, Medicinal values of garlic (Allium sativum L.) in human life: An overview. Greener Journal of Agricultural Sciences, 4 (6): 265-280.

Rehman, Z. U., \& Munir, M.T. 2015, Effect of garlic on the health and performance of broilers. Veterinaria, 3(1): 32-39.

Sawitri, E. 2003, Pengaruh Ekstrak Allium sativum terhadap Daya Tahan Mencit Balb/C yang Diinduksi Listeria monocytogenes. Tesis. Semarang: Program Pascasarjana Universitas Diponegoro.

Sethi, J. \& Singh, J, 2015, Role of Medicinal Plants as Immunostimulants in Health and Disease. Annals of Medicinal Chemistry and Research, 1(2): 1009.

Sherwood, L, 2011, Fisiologi Manusia: Dari Sel Ke Sistem. Edisi Keenam. Alih bahasa oleh Brahm U. Pendit, Jakarta: ECG Press.

Shoemaker, C.A., P. H. Klesius and J.A. Plumb, 1997, Killing of Edwardsiella ictaluri by macrophages from channel catfish immune and susceptible to enteric septicemia of catfish. Veterinary Immunology and Immunopathology, 58(2): 181-190.

Silverthorn, D. U., William, C.O., Claire, W.G., Andrew, C.S. dan Bruce, R.J, 2010, Human Physiology: an Integrated Approach. Fifth Edition. San Francisco: Pearson Benjamin Cummings.

Singh V.K., \& Singh D.K, 2008, Pharmacological Effects of Garlic (Allium sativum L.). ARBS Annual Review of Biomedical Sciences, 10: 6-26

Tortora, G.J. \& Derrickson, B, 2009, Principles of Anantomy and Psysiology, Twelfth Edition. USA: John Wiley \& Sons, Inc.

Untari, Ida, 2010, Bawang Putih sebagai Obat Paling Mujarab bagi Kesehatan. GASTER, 7(1): 547554.

Utami, P \& Mardiana L, 2013, Umbi Ajaib Tumpas Penyakit. Jakarta: Penebar Swadaya. 